\title{
The Problem of Authority: What Can Korean Education Learn From Dewey?
}

\author{
Sang Hyun Kim
}

\section{ABSTRACT}

While the ideas of Western democracy and individualism are increasingly popular and influential in Korean society, the traditional Korean understanding of authority has been challenged, especially in Korean schools. In this essay, the author first tries to analyze some important educational problems in contemporary Korea as it relates to the problem of authority. The paper, then, examines Dewey's ideas on authority and their connection to education and discusses what significance Dewey's view of authority might have on Korean education today. The author argues that Dewey's thoughts on education are especially applicable to contemporary Korea, a land in which there has been an upsurge in democratic aspirations in both society and education during recent decades.

\section{Introduction: Educational Problems in CONTEMPORARY Korea}

The importance of moral education and teachers' moral authority based on Confucianism ${ }^{1}$ has long remained the central feature of Korean education. Korean society, traditionally, not only granted teachers the same authority as parents, but more significantly, attributed to them even greater responsibility for children's moral and intellectual development (Sorensen, 1994, 27-28). In a circumstance in which the teacher is regarded as a moral exemplar and is given remarkable authority by parents to develop their children's moral character, as Sorenson (1994) observed, "the teacher's word is law ... The teacher's proper role is to impart truth. It is a rare student that would question a teacher's authority, whatever his or her private doubts" (27). Hence, teaching has been perceived as a highly respected profession in Korean society.

With the influence of Western democracy and increasing individualism since the 1987 civilian uprising, moral education and teacher authority have undergone a profound change. More specifically, in the face of a changing society in which the authoritarianism of the past is no longer sustainable, Koreans have increasingly accepted modern Western liberal values, resulting in a dramatic decline in obedi- 
ence to, and respect for, authority, including teachers in the classroom. The trend is particularly visible among young people in Korea. According to a recent international survey, it is observed that Korean youths, among those from 17 Asia-Pacific countries, are most reluctant to accept the moral values of the Confucian tradition and the least Confucian in terms of respect for adults or authority figures (see Yang, 2008, 94). Another survey conducted by the Korean Federation of Teacher Associations indicates that teachers themselves also perceive the speedy demise of the traditional value system in their work. The survey results show that many Korean teachers are currently experiencing increasing amounts of stress not only because of the overburden of classroom teaching and sundry administrative duties, but, more significantly, because of social criticism against them. Moreover, according to the survey, about 6 out of 10 teachers have reported that their job satisfaction and morale have significantly declined during the recent years. 66.4 percent of respondents cited the loss of teacher authority among students and parents as having the most significant impact on their satisfaction and morale (see The Korean Federation of Teacher Association News, June 22, 2009).

There is no doubt that the problem of moral education in Korean schools today is closely associated with the decline of teachers' moral authority, which has led to rapid erosion of the traditional Korean belief that moral values are transmitted through the voice of teachers. However, a more genuine problem of moral education in contemporary Korea is that, despite its success in rejecting the traditional authority, it has failed to find a new authority for moral guidance. As a result, the confusion and uncertainty about moral education persists, and there has accordingly been an absence of authority in Korean schools.

In this environment, Korean schools are rapidly moving towards only serving utilitarian or economic purposes. Moreover, as the 1997 Korean financial crisis ${ }^{2}$ has brought about increasing middle class insecurity, which has also led to intense competition among Koreans, the competition in contemporary Korean society has been especially severe in the context of education (Koo, 2007). Since the crisis, distinction through degrees and diplomas from more prestigious universities as vehicles for class mobility and stability has become more important than ever before. Hence, there has been an education frenzy, shared by all classes, involving utilizing resources to gain access to some of the nation's most elite universities and to obtain the skills that are perceived to be of greatest value in the global economy (Jarvis, 2008).

This frenzy among Korean parents to secure an elite education for their children has resulted in not only high enrollment and advancement rates at the primary, secondary, and college levels, but, more notably, the rapid explosion of the private educational market. For example, in 2003, the advancement rates from elementary to middle school and from middle school to high school were 99.9 percent and 99.7 percent, respectively (see International Bureau of Education, 2004). More recently, as of 2008 , the percentage of high school graduates who advanced to universities 


\section{SANG Hyun KIM}

or colleges reached 83.8 percent, which is among the highest in the world (Park, 2010). Despite this impressive factual data, Korean schools have become largely mistrusted by the general public because of their inability to avoid a system that is "too competitive, too exam-oriented with a single preoccupation to prepare students for college entrance exam" (Koo, 2007). As a result, Korean parents have turned to "off-school" private education opportunities, such as private tutoring and cram schools, in order to increase their children's chances to enter one of the elite universities. In particular, as private education is considered to be useful in terms of scoring higher on the college entrance exam, it has become an indispensable part of a Korean student's educational experience. ${ }^{3}$ Students and parents are thus more and more involved in private education, seeking out the best cram schools or private tutors in order to win the competitive educational race. As a result, there has been an explosion in the private market for educational advancement and advantage.

There is no doubt that wealthy families have taken the lead in private education and have intensified competition for entrance into the nation's most prestigious academic institutions (Koo, 2007). However, in the particular context of Korea, where education has long been a cultural aspiration and often regarded as the most important class marker, all social classes have participated in the private market of educational competition. ${ }^{4}$ This fierce competition starts from a very early age, even with kindergarten-aged children, resulting in enormous financial burdens for most families. Korean families currently spend a higher percentage of their household income on children's private education than any other OECD country (Kim and Lee, 2002; Ihm, 2008). For example, as of 2003, the private tutoring expenditure in Korea amounted to 12.4 billion US dollars, which was equivalent to about 56 percent of the national budget on schooling (Chong, 2005).

Under the burden of the overheated examination race and private after-school activities, Korean parents have also experienced greater psychological distress. Particularly after the economic crisis of 1997, in order not to be left behind in the race to earn prestigious degrees, which will lead to better jobs and income prospects as well as elite social status, every parent in Korea increasingly "watches over others' shoulders and wonders whether others are doing something better and smarter in preparing their kids for college entrance exams" (Koo, 2007). Perhaps not surprisingly, the most affected victims of Korea's unbridled education fever are the children themselves. According to comparative studies, during the so-called "Exam Hell," children in a contemporary Korea spend more time studying than any other country's counterparts (Seth, 2008, 216-17). While young Korean students spend the majority of their time preparing for the fact-oriented and rote-learning centered college examination, postponing all other pursuits until after the exam, it is not at all surprising that their levels of stress and unhappiness with school life are considerably high (OECD, 2004; Kim, 2006). Korean students' high levels of stress and unhappiness combine to delay their moral development and maturation. Un- 
fortunately, these delays have led to depression, illness, and even sometimes suicide. ${ }^{5}$ Moreover, in the environment of the society-wide education craze in which Korean young people are compelled to memorize factual information only associated with the college entrance exam, they have little time to freely explore their intellectual creativity and interests and enhance their physical and social development (Seth, 2008).

I have attempted so far to present some important educational problems in contemporary Korea as they relate to the problem of authority. I will now philosophically examine Dewey's views on authority and how they manifest themselves in his conception of education. Lastly, this study will discuss the significance of Dewey's philosophy for the possible redevelopment of Korean education today.

\section{DeWEy's IDEAS ON AUthority}

John Dewey, America's most notable philosopher of the $20^{\text {th }}$ century, was keenly aware of the challenged posed by the relationship between authority and freedom. In his address on 4 September 1936 at the Harvard Tercentenary Conference of Arts and Sciences, Dewey maintained that it is "the most difficult task human beings ever set their hearts and minds to attempt" (1987/1936, 145). In fact, being a person with a deep passion for 'freed intelligence,' his career can be seen to a great extent as an attempt to reconcile authority and freedom as well as to understand the problem of authority itself. More precisely, his intellectual search was undertaken to find a new kind of authority that gives individuals direction and support without being hostile to their freedom and social change. A close look at Dewey's ideas on authority reveals not only the tension that prevailed in the history of western culture between authority and freedom, but, more importantly, the possibility for the balance or harmony of these two important elements within human experience.

\section{Dualism and the Problem of Authority}

Dualism is something that Dewey consciously sought to overcome throughout his intellectual life. As Thomas Alexander (2006) writes,

Dualism may be taken to refer to a variety of philosophical positions or worldviews, but can also refer to a habit of thought in which a preliminary distinction is taken to designate two fundamentally exclusive categories. The result is that the spectrum of all phenomena must be understood in terms of either one or the other opposite, and so an initial clarifying contrast becomes a fixed over-simplification. In the West, philosophy has labored since its inception from a tendency to set forth important distinctions as grounded in separate types of being. (184)

Dewey believed that in western culture too much intellectual vigor has been spent on dualistic habits of thought, especially "the supposititious problem of relations" 
such as the subjective and the objective, the individual and the society, and freedom and authority (Dewey, 1991/1927, 192-93). The consequence, according to Dewey, has been not only a misunderstanding of the human condition but also frustration with the human endeavor in action. Opposing the dualism that had previously characterized Western philosophy, Dewey turned his intellectual attention to showing how the two concepts arise together in common experience.

The dualistic philosophy of freedom and authority, for Dewey, was a product of particular historical events; more precisely, the revolt against authority. At first, the historic revolt, perhaps originating as early as the Renaissance and the Reformation, was directed against the institutions of the church and the state themselves. Later, the assault spread "to science and art, to standards and ideals of economic and domestic life" since the control exercised by them "had entered into all phases and aspects of life, in belief and conduct alike" (Dewey, 1987/1936, 130). Then, like any other practical movement, this revolt needed to be defended on intellectual grounds. In the process of justification, a systematic idea that seemed, for many, to be like the summary of a profound social and political philosophy, was developed. Regarding this new-fangled system of thought, Dewey (1987/1936) writes,

According to the formula, the one great intellectual problem is the demarcation of two separate spheres, one of authority and one of freedom; the other half of the formula is to maintain this theoretical demarcation as a sharp division in practice. The formula has a corollary. The inherent tendency of the sphere of authority is to encroach on the sphere of freedom, thus enstating oppression, tyranny, and, in the language of today, regimentation. Hence the right of way must belong to the idea and actuality of individual freedom; authority is its enemy, and every manifestation of social authority and control is therefore to be zealously watched, and almost always to be vigorously opposed. However, since the sphere of liberty has its boundaries, when 'liberty' begins to degenerate into 'license' the operation of authority is properly to be called upon to restore the balance. (130-31)

In its dual character, Dewey asserts that this formula "celebrates, with one hand, the decay of the institutions which had exercised sway over men's minds and conduct; and, with the other hand, it signals the rise of the new social and intellectual forces" (1987/1936, 131-32). With this formula, the established organizations or institutions were to reject and subdue innovative forces aiming to create new beliefs and new modes of human association in order to preserve their obsolete traditions. While the former was regarded as the one that deprived individuals of their freedom, the latter became the only one that liberated individual freedom. It is therefore understood that authority is inherently both external to individuals and hostile to freedom and social changes. Unfortunately, the final result of the historic conflict between the old and the new, according to Dewey, was the classical philosophy of liberalism that challenged any form of authority. 
Notwithstanding its deep relevance in the historic events of western culture in recent centuries, Dewey claims that this dualistic principle that presented authority and freedom as two mutually exclusive "spheres," the former implying tyranny and regimentation and the latter signifying individual freedom, is an absurd guide to understanding and action. For it evades the real problem. Instead of providing a means of coping with this historic struggle, he pointed out that it merely presents as "a solution what is none other than a theoretical transcript of the nature of the conflict itself" (Dewey, 1987/1936, 132). After all, the widespread adoption of this false and misleading dualism, he believes, brought about the present state of confusion, intellectually and practically, with respect to the subject of authority. While considering the sharp separation between freedom and authority as bizarre, Dewey (1987/1936) argued that the genuine problem is the interpenetration of these two principles:

Authority stands for stability of social organization by means of which direction and support are given to individuals; while individual freedom stands for the forces by which change is intentionally brought about. The issue that requires constant attention is the intimate and organic union of two things: of authority and freedom, of stability and change. (131)

Dewey therefore believed that there is an intimate connection between the principle of freedom and the principle of authority. In a healthy society, he believed that individuals were in need of authority as much as they were in need of freedom. In this regard, the real problem is not to separate but rather to find out the proper relationship between them so that better understanding and action can come about in experience. Hence, it became obvious for Dewey that there was a pressing need to rethink the problem of authority and freedom in such a way that the two were properly integrated.

\section{Dewey as a Philosopher of Authority}

Dewey argues that man is constantly in need of authority. This need, he writes, "is a need for principles that are both stable enough and flexible enough to give direction to the process of living in its vicissitudes and uncertainties" (Dewey, 1946, 169). John Diggins (1995) characterized Dewey as follows: "although regarded by liberals as the philosopher of freedom, Dewey was no less a philosopher of authority, and he aspired as much as any conservative moralist to make authority a viable concept in the modern world" (226). In an article entitled "Authority and Social Change," his most explicit discussion regarding the nature of authority, Dewey (1987/1936) claims,

We need an authority that, unlike the older forms in which it operated, is capable of directing and utilizing change and we need a kind of individual freedom unlike that which the unrestrained economic liberty of individual has produced and justified; we need, that is, a kind of individual freedom that 


\section{SAng HyUn KIM}

is general and shared and that has the backing and guidance of socially organized intelligent control. (137)

It is therefore apparent that the new system of authority he had in mind did not oppose change, but rather encouraged it. In addition, it would sustain the principle of freedom for all individuals, not just for the economically powerful.

This new form of authority, in Dewey's judgment, would not be found by looking to the path of history. In his words,

Neither the past nor the present afford ... any ground for expecting that the adjustment of authority and freedom, stability and change, will be achieved by following old paths. The idea that any solution at all can ever be attained may seem to some romantic and utopian. But the most fantastically unrealistic of all notions, is the widely prevalent belief that we can attain enduring stable authority by employing and, where necessary, by re-exhuming the institutional means tried in the past. (Dewey, 1987/1936, 140)

Dewey made it clear that a return to an external form of authority would not succeed in solving the problem between authority and freedom. The method of external authority, he reasoned, would ultimately be susceptible to attack as other external forms had been in the past (Dewey, 1987/1936, p. 141). The source of authority that has not yet been tried on any large scale in human relationships and that may bring the actual possibility of successful application, Dewey (1987/1936) suggests, is "the utilization of organized intelligence, the manifold benefits and values of which we have substantial and reliable evidence in the narrower field of science" (p. 141). Specifically, Dewey asserted that the operation of organized intelligence displayed in science represented a remarkable union of freedom and authority. On the one hand, he said, science has progressed by releasing, not suppressing, the variable and creative dimensions of human beings. Its advances have been initiated by individuals who freed themselves from the bonds of tradition and custom whenever they have found the latter hampering their own powers of reflection and observation. On the other hand, despite the development of science as dependent on the freedom of individual inquirers, Dewey writes that

the authority of science issues from and is based upon collective authority, cooperatively organized. Even when, temporarily, the ideas put forth by individuals have sharply diverged from received beliefs, the method used has been a public and open method which succeeded and could succeed only as it tended to produce agreement, unity of belief among all who labored in the same field. Every scientific inquirer, even when he deviates most widely from current ideas, depends upon methods and conclusions that are a common possession and not of private ownership, even though all of the methods and conclusions may at some time have been initially the product of private invention. The contribution the scientific inquirer makes is collectively tested and developed and, in 
the measure that it is cooperatively confirmed, becomes a part of the common fund of the intellectual commonwealth. $(1939,359)$

Therefore, in the field of science, advance and progress have occurred when individual freedom and collective authority are effectively working together. In other words, scientific inquiry reveals how authority and freedom can support each other to advance human society and its knowledge (Gordon, 1998, 242). It becomes obvious that this operation of organized intelligence in the natural sciences was a model for Dewey for the kind of freedom and authority necessary in social affairs. It was his genuine desire that the method of collective and cooperative intelligence, working with the release of individual powers and capabilities, might be ultimately extended to the larger field of human relations, though he was uncertain that the extension would produce the desired result. Nevertheless, Dewey asserted that "the problem of the relations of authority and freedom, of stability and change, if it can be solved, will be solved in this way" (Dewey, 1987/1936, 144).

In summary, Dewey promoted authority in the method of organized intelligence as exemplified in the area of science. The authority gained by organized intelligence, as exemplified by the use of scientific inquiry, was based on shared ideas and understanding. The authority itself favored reform and development that was dependant on the free and equal participation of all individuals. Accordingly, the problem of authority, for Dewey, could be resolved only in the framework of a democratic society. And he asserted that the effort necessary to achieve this humanly desirable and humanly necessary outcome was well spent:

The failure of other methods and the desperateness of the present situation will be a spur to some to do their best to make the extension actual. They know that to hold in advance of trial that success is impossible is a way of condemning humanity to that futile and destructive oscillation between authoritative power and unregulated individual freedom to which we may justly attribute most of the sorrows and defeats of the past. They are aware of the slow process of history and of the unmeasured stretch of time that lies ahead of mankind.... No matter how slight the immediate effect of their efforts, they are themselves, in their trials, exemplifying one of the first principles of the method of scientific intelligence. For they are projecting into events a comprehensive idea by experimental methods that correct and mature the method and the idea in the very process of trial. The very desperateness of the situation is for such as these but a spur to sustained, courageous effort. (Dewey, 1987/1936, 145)

\section{The Reconstruction of Authority in Education}

Regarding the life of the child as the "all-controlling aim" of the school, Dewey once famously wrote that "the child becomes the sun about which the appliances of education revolve; he is the center about which they are organized" (Dewey, 


\section{SANG HyUn KIM}

2001, 35-36). It is therefore not surprising that Dewey was not content with the image and exercises of authority in traditional schools, which promoted the automatic obedience of the child to teacher control, ignoring the child's individuality. However, it is also not true that he completely rejected the principle of authority in the educational arena. Consistent with his philosophical writings on authority discussed in the previous section, Dewey recognized the need to find a new, more effective source of educational authority, especially in encouraging a more genuine interaction between teachers and students that will enhance the experience of children and their continued growth. In his own words,

When external authority is rejected, the problem becomes that of finding the factors of control that are inherent within experience. When external authority is rejected, it does not follow that all authority should be rejected, but rather that there is need to search for a more effective source of authority. Because the older education imposed the knowledge, methods, and the rules of conduct of the mature person upon the young, it does not follow, except upon the basis of the extreme Either-Or philosophy, that the knowledge and skill of the mature person has no directive value for the experience of the immature. On the contrary, basing education upon personal experience may mean more multiplied and more intimate contacts between the mature and the immature than ever existed in the traditional school, and consequently more, rather than less, guidance by others. $(1998 / 1938,8)$

What, then, is the more effective source of authority that Dewey has in mind regarding education? Consistent with the conception of authority in his philosophical writings, Dewey put the collective intelligence of a classroom or school community as a whole in the place of a new educational authority. In Experience and Education, he makes this clear by discussing how social control (authority) should be exercised in the classroom. Dewey argues that "it is not the will or desire of any one person which establishes order but the moving spirit of the whole group. The control is social, but individuals are parts of a community, not outside of it" $(1998 / 1938,58)$. Therefore, according to Dewey, effective educational authority is to be exercised in a social context, where individuals, including the teacher, are involved and contribute to and participate in its common activities and understandings. In this way, Dewey insists that the principle of social control does not necessarily restrict the principle of personal freedom. Moreover, under such a condition, where the uncoerced consensus of social control prevails, he maintains that individuals in the classroom community, especially children, do not feel that they are submitting to external imposition even if they are called to order.

Dewey is, however, fully aware that there are occasions when teachers need to intervene and exercise their personal authority over students. When such a situation occurs, the exercise of teachers' authority, he claims, should be done for the good of the whole: 
The teacher reduces to a minimum the occasions in which he or she has to exercise authority in a personal way. When it is necessary, in the second place, to speak and act firmly, it is done in behalf of the interest of the group, not as an exhibition of personal power. This makes the difference between action which is arbitrary and that which is just and fair. (Dewey, 1998/1938, 59)

In this respect, for Dewey, it is the right and responsibility of the teacher to use his or her personal authority over children in situations where it is necessary or inevitable. He also believed that the use of teacher control, according to the principles of justice and equality, does not necessarily lead to harmful results for the individual children involved or for the classroom community as a whole (Gordon, 1998). Therefore, the concept of teacher authority indeed does not disappear in Dewey's educational thought. Rather, it becomes "more subtle, less oppressive, and, he assumed, more effective" (Cassidy, 1980, 13).

Dewey further discusses in Experience and Education that teachers face the problem of classroom control not because of difficult, unruly children, but rather because of a lack of advanced planning. Teachers' sufficient planning in advance, he argues, "will create situations that of themselves tend to exercise control over what this, that, and the other pupil does and how he does it" (Dewey, 1998/1938, 63). Hence, Dewey, unlike some proponents of progressive education, insists that advanced planning by teachers to direct instruction and classroom activities is necessary and, more importantly, not inherently hostile to the freedom of students. In his words, he wrote,

I do not know what the greater maturity of the teacher and the teacher's greater knowledge of the world, of subject-matters and of individuals, is for unless the teacher can arrange conditions that are conducive to community activity and to organization which exercises control over individual impulses by the mere fact that all are engaged in communal projects. Because the kind of advanced planning heretofore engaged in has been so routine as to leave little room for the free play of individual thinking or contribution due to distinctive individual experience, it does not follow that all planning must be rejected. On the contrary, there is incumbent upon the educator the duty of instituting a much more intelligent, and consequently more difficult, kind of planning. (Dewey, 1998/1938, 64-65)

Dewey therefore calls upon teachers to cultivate the habit of more thoughtful planning in advance and to bring it into their classrooms, and this is in fact more difficult than preparation in traditional schools. With respect to such planning, teachers, he maintains, must do it with both flexibility and direction. More precisely, for Dewey, the planning of the teacher must be flexible enough to make room for his or her students' personal initiative and creativity. At the same time, the planning, however, must be firm and able to provide direction for the continuous development of the students. In this way, the teacher, through the medium of more intelligent 


\section{SANG HyUn Kim}

planning, plays a vital role in terms of enhancing educational authority by fostering "individual efforts with collective control" (Gordon, 1998, 254-55).

Therefore, it seems that Dewey wanted teachers to act as leaders in the community rather than dictatorial outsiders. The teacher, he states, as the most mature and experienced member of the school community, "has a peculiar responsibility for the conduct of the interactions and intercommunications which are the very life of the group as a community" (Dewey, 1998/1938, 66). Further, for Dewey, as much as the freedom of students is important in the school community, the freedom of the teacher as a member and leader of the group must be respected as well. The teacher, he said, should not be afraid to make suggestions to the students regarding what they should do in the classroom and its activities. Regarding the importance of teachers' experience and active involvement in giving suggestions, Dewey writes,

I have heard of cases in which children are surrounded with objects and materials and then left entirely themselves, the teacher being loath to suggest even what might be done with the materials lest freedom be infringed upon. Why, then, even supply materials, since they are a source of some suggestion or other? But, what is more important is that the suggestion upon which pupils act must in any case come from somewhere. It is impossible to understand why a suggestion from one who has a larger experience and a wider horizon should not be at least valid as a suggestion arising from some more or less accidental source. $(1998 / 1938,84-85)$

Hence, as Putnam and Putnam (1993) point out, Deweyan progressive education clearly does "not let children run wild" (366). In his mind, the real development of children does not occur in a spontaneous and uncontrolled way. On the contrary, it is the business of the teacher, Dewey argues, to arrange external conditions that may affect the educational experience of children without imposing a mere control. Such conditions should help children to activate their individual interests and intelligence and also enable them to make their own special contribution to the democratic educational community (Dewey, 1998/1938, 301).

Although it appears that the teacher in Dewey's educational theory does not have a "clear-cut authority," he or she is in fact the one who has real power in shaping an educational environment that will lead to the positive growth of children. Indeed, he or she has a difficult and daunting task--to guide children not only to have a more educative experience, but also to become a more effective democratic members of the community for the present as well as for the future. As the representative of both democratic society in general and democratic education in particular, the teacher, in Dewey's school, is "as important as ever" and "continues to represent an authority, yet his authority is no longer explicit: it now is hidden and disguised" (Rosenow, 1993, 217). The educational philosophy of Dewey is in this way teacher-centered as much as it is child-centered (Petrovic, 1998, 517). 


\section{What Korean Education Can Learn from Dewey}

Few in contemporary America would dispute Dewey's deeply significant contribution to America's intellectual life. For example, Henry Steele Commager (1950), an influential intellectual historian, declared that Dewey was "the guide, the mentor, and the conscience of the American people: it is scarcely an exaggeration to say that for a generation no major issue was clarified until Dewey had spoken" (100). Morris Cohen (1954), one of Dewey's strongest critics, provides another measure of Dewey's brilliance by confidently asserting that "John Dewey is unquestionably the pre-eminent figure in American philosophy; no one has done more to keep alive the fundamental ideals of liberal civilization; and if there could be such an office as that of national philosopher, no one else could be properly mentioned for it" (p. 290). More recently, Louis Menand, a prominent American writer, argued that Dewey's ideas "changed the way Americans live — the way they learn, the way they express their views, the way they understand themselves, and the way they treat people who are different from themselves" (2001, p. xi).

I have no quarrel with these assessments regarding Dewey's influence on American life. However, I contend that we must not fall into the trap of believing that Dewey's philosophy belongs and applies only to America. More precisely, as James Wheeler (1954) pointed out, we should "not allow their truth to cause us to forget that Dewey's views are of vital import and provide a coherent purpose to any environment where men are not afraid of freedom, where inquiry is treasured, and where diversity is recognized as one of the great hopes and not the despair of man" (89). In short, the philosophical and educational thought of John Dewey are of great relevance and importance to a modern society. His contributions gain even greater importance when we think more seriously about the necessity of education and its proper place in a rapidly changing democracy (Boisvert, 1998, 159; Hook, 1973, 26).

For this reason, John Dewey's thinking about education is especially applicable to contemporary Korea, a land where there has been an upsurge in democratic aspirations in both the larger society and education during recent decades. The question for current Korean education is similar to the question Dewey raised in the early twentieth century about American education. ${ }^{6}$ The question is, How do we understand education and teacher authority in light of modern democracy and individualism?

In what remains, I discuss the impact Dewey's ideas on authority might have on Korean education today. First, it is the idea of integration, not conflict, between authority and freedom that is at the heart of his philosophy. In Korea, the traditional aim of education was to provide the means to become a superior, cultured man, or what has become known as the Confucian gentleman. Such men were to take their place as teachers through living ethical principles; therefore, teachers and their authority were highly respected by traditional society in Korea and its authorities. However, this is not the case in Korea today. With the influence of western liberal 
democracy and individualism in Korea, while the decrease of teacher authority is obvious, students and their parents do not hesitate to challenge existing authority in schools. In such circumstances, Koreans increasingly tend to see teacher authority and student freedom as opposing forces, and thus insist upon one at the expense of the other. This dualistic approach, as Dewey observed, is frivolous in that it will not only provide an incorrect analysis of the problem of authority and freedom, but will also offer no solution to the problem.

In other words, Dewey's call for a non-dualistic understanding offers Korean education important insights for confronting the challenges of the authority crisis and moral education. First, those who approach the problem of authority from a non-dualistic standpoint will observe that the principle of authority is not necessarily a threat to the principle of freedom. Because the opposition of these two principles is unreasonable and unnecessary, it is important then to understand how authority relates to freedom. In Deweyan schools, students need authority or discipline as much as they need freedom, and these two principles are thus partners, not antagonists. Second, Dewey's non-dualistic outlook will not lead us to rush to judgment or to conclude that morality in Korea, especially among the young generations, is "lost" in the isolation of widespread Western individualism, and that there is thus an urgent need for the restoration of the traditional authoritarian teacher in the classroom. Third, Dewey's non-dualistic conception of freedom and authority would enable Korean education to avoid falling into the trap of complete or absolute rejection of any form of authority by readily indentifying freedom with the absence of authority. This strongly suggests the need for Korean education to search for and develop a new educational authority that can provide individuals with vital directions and effective freedom in a rapidly changing and complex society. Fourth, with respect to moral education, Dewey's non-dualistic thinking implies that the intent is not to impose (e.g., through indoctrinate) some ready-made standards and traditions on students, but rather to help them make responsible and intelligent decisions. Moral education, for Dewey, thus extends over all aspects of human conduct and experience, such that all free and deliberate choices fall within the domain of moral judgment and significance. In short, Dewey's integrative approach forces Korean schools consider new, heretofore unseen, alternatives; it further compels school and policy makers to be more rigorously involved in solving the problems of the authority crisis and moral education, instead of residing in the easy but perilous refuge of the dichotomy that crudely oversimplifies the issues.

The second of his ideas that is relevant to Korean education is Dewey's elevation of intelligence to the status of authority. For Dewey, intelligence is not merely about using mind in the acquisition of factual information and of certain technical skills in human life. Rather, it is the power to think of available information and acquired knowledge with deliberate reflection and to relate them to current issues in experience. It is also the ability to frame worthwhile aims and organize a means 
to carefully execute and realize them. This means that intelligence is not something to be quantified, but is rather a process that is continually changing and moving in life experience (Dewey, 1998/1938, 77; Dewey, 1998/1917, 52). The business of a teacher, Dewey argues, is to help students to develop such intelligence and continually increase in that power. In contrast, the business of a teacher in contemporary Korean education is only to prepare students for college entrance exams. Students, especially in secondary schools, learn only the content that might relate to the examination; schools, to a great extent, ignore some subjects, such as history, geography, music, and physical education, because they simply do not have much significance in the entrance examination. In such an excessive fervor for test-driven education, Korean students spend most of their time on rote learning.

From a Deweyan perspective, it is obvious that Korean education deprives its students of the opportunity to assist the practice and growth of their own intelligence. With the focus of Korean education on improving test scores, its students' outstanding performance in international competition via standardized tests is not at all surprising. However, if we take Dewey's view of intelligence seriously, as much as Korean students' excellent performance on standardized testing can be the distinguishing feature of Korean educational success, it can also be a mark of the failure of Korean education. This is because Korean education is, in the midst of a test-driven education system, failing to help children develop their capacities to think clearly and to judge critically by not furnishing a proper learning environment for both moral development and non-moral learning in schools. Additionally, Dewey's view of intelligence allows Korean schools to reconsider the meaning of "intelligent being" at the practical level. More specifically, Dewey's concept of intelligence as a quality of process, rather than a fixed quantity, would suggest that the test scores cannot accurately represent the academic or intellectual abilities of Korean students. In other words, students who have obtained higher scores on school subject tests or college entrance examinations that feature only a few overemphasized subjects do not necessarily qualify as intelligent beings. The application of this Deweyan view to Korean education would mean beginning to pay attention to many different aspects of student intelligence and, subsequently, to give a balanced emphasis on cultivating those varied qualities that include artistic, original skills and organizational, discerning abilities in the assessment of college entrance exams as well as in the school curriculum and practice. In sum, Dewey reminds Korean educators that while the freedom of intelligence is the only freedom of enduring importance, the continued development of intelligent reflection, judgment, and action is the way to become genuinely free $(1998 / 1938,69-70)$.

The Third of Dewey's relevant ideas for Korean education is the collective and democratic model of authority. It is based on shared ideas and understanding, and its development is dependent on free and continuous participation by all individuals. Accordingly, it is a democratic authority that rests and makes claims on com- 
munication. Dewey's democratic conception of authority is especially noteworthy in relation to the contemporary Korean education system. Since the 1987 civilian uprising, on the one hand, Korea has made significant strides toward building a democratic society. On the other hand, however, in the process of dismantling authoritarianism, Korean society has encountered a rapid decline in social cohesion and widening conflict between interest groups. In particular, through the economic crisis of 1997 and subsequent neoliberal reforms, Korean democracy has turned into competition for material wealth and survival in a harsh competitive environment. As a result, Koreans increasingly experience a loss of community and undergo profound segmentation and specialization in modern life. Liberal economic ideas have entered deeply into education in Korea. In the name of efficiency, a top-down approach prevails in Korean education. The decision-making process is highly centralized, and schools are filled with hyper-rational, policy-driven goals. While the implementation of policy takes precedence over the education of children, schools themselves are competing with each other for their own survival in order to increase the numbers of students who enter more prestigious universities just as much as children in the classrooms try to get ahead of their classmates. In such a situation, schools function as a place to learn the same things in the same way at the same time, and this discriminates children through the pretense of standardization. Those students who are left behind in the completion are often falling into, or are at the greatest risk for, delinquency.

From a Deweyan perspective, the solution to these problems in contemporary Korea is not to move toward a restoration of arbitrary authority. Rather, it lies in the establishment of an authentic democratic authority based on shared common interests, communication, and experience. With regard to education, the solution is to create a more democratic learning community in which all individuals, not just the teacher, can participate in the exercise of the educational process and its power. More specifically, it is the cooperative and intelligent classroom community that utilizes genuine authority by engaging in give and take discussion and formulating classroom procedures and polices. In such a democratic setting, it is clear that education is more than going faster toward determined goals, nor is it like modern capitalistic authority and its methods of cost-benefit analysis. It is, moreover, not just for a few privileged students who take advantage of unhealthy competition and achieve at the expense of others. Instead, education is concerned with the growth and development of every human life. While diversity among children and variation in their development is respected, every teacher is honored as a leading, contributing member within the richness of the school community.

Therefore, Dewey's vision of democratic schools offers Korean education a balance between individual initiative and communal cooperation. It urges students to explore their interests and strengths, and to share them with others through the intelligent leadership of the teacher. For example, in a Deweyan school, instead of 
solely piling up facts or information in the children's head in a quiet classroom, the teacher would give students, both individually and collectively, time to investigate social and environmental issues that are of interest to them and to present their findings to their classmates in accessible means and modes of communication of their choice. With the multiplicity of experiences that students bring to the classroom, collaboration and communication could be challenging and often intimidating. However, as Dewey understood, the challenge of these cooperative activities is that they open up the possibility for bringing enrichment to one's own experience as well as offering that enrichment to other students. The effort to communicate with others would help students to get out of their own comfort zone and habitual perspectives. It would encourage students not only to think for themselves and find ways to connect and share their ideas with others, but, perhaps more importantly, to learn to think from, and show respect for, other people's perspectives. Thus, as teachers allow and encourage collaborative learning and communication in their classrooms, they are indeed helping children to learn to live in a democracy and develop a more democratic society.

It was Dewey's conviction that the real problem of modern educational institutions was not the result of an inherent weakness in human nature or democracy, but rather of the failure of these institutions to promote democracy (Johnson, 1995, 104). His call for a democratic reconstruction of education based on the principle of experience is in fact an attempt to make learning a unified process and to enhance its integrity. If Dewey was speaking to Korean educators today, he might say that,

In society and in the schools there is a whole series of conflicts between older and newer ideals, beliefs, practices. The confusion and incoherency are due to this conflict. The creation of a unifying aim in education in its relation to society does not mean that educators need a blueprint of what society should be, and then teach according to it. They do need a sense of direction of movement. It is possible to exaggerate greatly the direct influence of schools upon the formation of social and institutional life. It is not possible to exaggerate their responsibility with reference to the effect of what they do upon the formation of the attitudes, intellectual and moral, of the youth who are to determine the direction future society will take.

The unity that was the product of the almost unquestioned acceptance of old aims and procedures has been lost through the invasion of studies, methods, courses, and types of schools that correspond to social forces that have grown in intensity and significance. To carry on we need a clearer vision of the new forces and the courageous will to make them victorious all along the line. Without the vision we shall continue to be confused. Without the courageous will we shall be dismayed at the powerful interests that are eager to defeat the educational process in order to make the schools the subservient instrument of their own special purposes, and shall, whether knowing it or not, retreat 
from the struggle without having put up a fight for the integrity of education. (Dewey, 1985/1936, 11)

\section{ACKNOWLEDGMENTS}

This work was supported by a National Research Foundation of Korea Grant funded by the Korean government [NRF-2011-354-B0067].

\section{Notes}

1. Confucianism is an ideal moral system based on the thought of Confucius (551-479 $\mathrm{BC}$ ), a Chinese teacher and philosopher. It stresses the importance of both personal morality and the proper behavior of government. It seeks to define how persons should live together in a productive and wholesome society. Confucian thought has been greatly influential throughout East Asia, in countries such as China, Korea, Japan, and Vietnam. According to Confucius, there are five basic social relationships existing in human life: 1) father (kindness)/son (filial piety), 2) elder brother (gentility)/younger brother (humility), 3) husband (righteous behavior)/wife (obedience), 4) elder (consideration)/junior (deference), and 5) ruler (benevolence)/subject (loyalty). In each relationship, while the weaker or younger person submits to the stronger or older person, the stronger person is responsible for protecting the weaker one. (For an informative study of Confucianism, see Hopfe, 1994. For its influence on East Asia, see Tu, 1996.)

2. Economists argue that one of the important failures in the Korean government's economic policy was its inability to establish new mechanisms to effectively deal with the potential consequences of opening financial deregulation. For a detailed discussion and analyses of the causes and nature of the economic crisis, see Chang, Park, and Yoo (1998).

3. Almost 90 percent of parents and students believe that "off-school" educational opportunities such as cram schools and private tutoring are beneficial in preparation for the college entrance exam (Kim, 2006).

4. Notwithstanding class status becoming less important, such distinctions are still present in Korean society and its people. However, unlike other periods of Korean history, class status in contemporary Korea is not inherited but is achieved through economic and/ or educational success via hard work. In fact, economic success alone, without educational achievement, is often not enough to obtain elite status.

5. According to the surveys administered by the Korea Teachers \& Educational Workers Union and the Korea Youth Counseling Institute, almost half of the students reported contemplating suicide. The National Statistical Office estimates that as many as 1000 Koreans between the ages of 10 and 19 have committed suicide between 2000 and 2003, whereas the National Assembly by the Ministry of Education found that 462 middle and secondary school students committed suicide in the last 5 years (Card, 2005; Lee and Larson, 2000).

6. A detailed comparison between America in Dewey's time and contemporary Korea is outside the scope of the present study. However, it should be mentioned that Korea is currently experiencing significant social, economic, and political changes as did America in Dewey's time (See Lee, 2000, 73). Most of all, the problem of authority in Korea, which is fostered by these dramatic cultural changes, is similar to, if not exactly the same as, the problems the United States faced at the time. 


\section{REFERENCES}

Alexander, Thomas M. "Dewey, Dualism, and Naturalism." In A Companion to Pragmatism. Edited by John R. Shook and Joseph Margolis. Oxford: Blackwell Publishing, 2006. doi:10.1002/9780470997079.ch18.

Boisvert, Raymond D. John Dewey: Rethinking Our Time. Albany, NY: State University of New York Press, 1998.

Card, James. "Life and Death Exams in South Korea." Asia Times, November 30, 2005.

Cassidy, Keith M. "John Dewey and the Problem of Authority." Educational Resources Information Center (ERIC), 1980.

Chang, Ha-Joon, Hong-Jae Park, and Chul Gyue Yoo. "Interpreting the Korean Crisis: Financial Liberalization, Industrial Policy and Corporate Governance." Cambridge Journal of Economics 22 (1998), 735-46. doi:10.1093/cje/22.6.735.

Cohen, Morris Raphael. American Thought: A Critical Sketch. Glencoe, IL: Free Press, 1954.

Commager, Henry Steele. The American Mind. New Haven, CT: Yale University Press, 1950.

Dewey, John. "Authority and Social Change." In John Dewey: The Later Works. vol. 11. Edited by Jo Ann Boydston. Carbondale: Southern Illinois University Press, 1987. (Original work published 1936).

Dewey, John. Democracy and Education. New York: The Free Press, 1966. (Original work published 1916).

Dewey, John. Experience and Education. West Lafayette, IN: Kappa Delta Pi, 1998. (Original work published 1938).

Dewey, John. "The Integrity of Education." The Education Digest, 51(1985, November), 9-11 (Original work published 1936).

Dewey, John. "The Need for a Recovery of Philosophy." In Larry A. Hickman and Thomas M. Alexander (Eds.), The Essential Dewey: Pragmatism, Education, Democracy. vol. 1. Edited by Larry A. Hickman and Thomas M. Alexander. Bloomington: Indiana University Press, 1998. (Original work published 1917). Dewey, John. Problems of Men. New York: Philosophical Library, 1946.

Dewey, John. The Public and Its Problems. Athens, OH: Swallow Press, 1991. (Original work published 1927).

Dewey, John. The School and Society \& The Child and the Curriculum. Mineola, NY: Dover, 2001.

Dewey, John. "Science and the Future of Society." In Intelligence in the Modern World: John Dewey's Philosophy. Edited by Joseph Ratner. New York: Modern Library, 1939.

Diggins, John Patrick The Promise of Pragmatism: Modernism and the Crisis of Knowledge and Authority. Chicago: The University of Chicago Press, 1995.

Gordon, Mordechai. "John Dewey on Authority: A Radical Voice within the Liberal Tradition." Educational Philosophy and Theory, 30 (1998), 239-58. doi:10.1111/j.1469-5812.1998.tb00326.x. 


\section{SANG Hyun Kim}

Hook, Sidney. "Landmarks in the Literature." New York University Education Quarterly, 5 (1973).

Hopfe, Lewis M. Religions of the World (6 ${ }^{\text {th }}$ ed.). New York: Macmillan College Publishing, 1994.

Ihm, Chon Sun. “The Political Economy of Educational Reform.” In Social Change in Korea. Edited by Kim Kyong-Dong and the Korea Herald. Paju-si, Korea: Jimoondang, 2008.

International Bureau of Education. Quality Education for All Young People: Challenges, Trends, and Priorities: National Report of the Republic of Korean by Ministry of Education and Human Resource Development. September 2004.

Jarvis, Jonathan A. "Globalization, Economic Capital and Higher Education in South Korea." Paper presented at the annual meeting of the American Sociological Association Annual Meeting, Boston, MA, 2008.

Johnson, Tony W. Discipleship or Pilgrimage?: The Educator's Quest for Philosophy. Albany: State University of New York Press, 1995.

Kim, Mee Sook. "Educational Research at KEDI and Its Relations to Policy and Practice in Korea." The NIER Regional Meeting of Educational Policy Research and Development Institutes, Tokyo, 2006.

Kim, Sun Woong, \& Ju Ho Lee. "The Secondary School Equalization Policy in South Korea." Working Paper, KDI School of Public Policy and Management, 2002.

Korean Federation of Teacher Associations News, The. Teacher Survey, June 22, 2009.

Koo, Hagen. "The Changing Faces of Inequality in South Korea in the Age of Globalization." Korean Studies 31 (2007), 1-18. doi:10.1353/ks.2008.0018.

Lee, Chong Jae. "Korean Education Fever and Private Tutoring." KEDI Journal of Educational Policy 2 (2005), 99-107.

Lee, Meery and Reed Larson. "The Korean 'Examination Hell': Long Hours of Studying, Distress and Depression." Journal of Youth and Adolescence 29 (2010, Summer), 249-71. doi:10.1023/A:1005160717081.

Lee, Joo Han. "A Study on Educational Programs to Realize Social Democracy in Dewey's Philosophy." The Korean Journal of Philosophy of Education, 23 (2000), 73-100.

OECD. Learning from Tomorrow's World: First Results from PISA 2003. Paris: OECD, 2004.

Park, Tae-Gyun. "Korea's Phenomenal Post-War Development." Koreana, 24(2010), 22-27.

Petrovic, John E. "Dewey is a Philistine and Other Grave Misreadings." Oxford Review of Education 24 (1998), 513-20. doi:10.1080/0305498980240406.

Putnam, Hilary and Ruth Anna Putnam. "Education for Democracy.” Educational Theory 43 (1993), 361-76. doi:10.1111/j.1741-5446.1993.00361.x.

Rosenow, Eliyahu. "Plato, Dewey, and the Problem of the Teacher's Authority." Journal of Philosophy of Education 27 (1993), 209-20. doi:10.1111/j.1467-9752.1993. tb00656.x. 
Seth, Michael J. Education Fever: Society, Politics and the Pursuit of Schooling in South Korea. Honolulu: University of Hawaii Press, 2002.

Seth, Michael J. "Korean Education Needs Fundamental Reform." In Social Change in Korea. Edited by Kim Kyong Dong and the Korea Herald. Paju-si, Korea: Jimoondang, 2008.

Sorensen, Clark W. "Success and Education in South Korea." Comparative Education Review 38 (1994), 10-35. doi:10.1086/447223.

Tu, Wei-Ming. Confucian Traditions in East Asian Modernity. Cambridge: Harvard University Press, 1996.

Wheeler, James E. “The Thought of John Dewey in Its Historical Setting.” Educational Theory 4 (1954), 87-94. doi:10.1111/j.1741-5446.1954.tb01085.x.

Yang, Jong Hoe. “Changing Values Cause Ideological Confusion.” In Social Change in Korea. Edited by Kim Kyong-Dong and the Korea Herald. Paju-si, Korea: Jimoondang, 2008.

Sang Hyun Kim received his $\mathrm{PhD}$ in philosophy of education from Ohio State University in 2011. He is currently teaching at Gyeongin National University of Education in South Korea.

E-mail: utsdohko@gmail.com. 